\title{
ESTIMATION OF SERUM INTERLEUKIN-18 IN HEPATITIS C PATIENTS IN ZAGAZIG UNIVERSITY HOSPITALS
}

\author{
Manal Mohammad El-Amin ${ }^{1}$, Mohamed Naguib El-Khashab ${ }^{2}$, Hoda Abdeen Ibrahim ${ }^{1}$ \\ and Afnan Anis El-Wakeel ${ }^{3}$ \\ ${ }^{1}$ Clinical Pathology Department, Faculty of Medicine, Zagazig University, Egypt \\ ${ }^{2}$ Tropical Medicine Department, Faculty of Medicine, Zagazig University, Egypt \\ ${ }^{3}$ Mit-Ghamer Central Hospital, Mansoura, Egypt
}

Received: 14 October 2018

Accepted: 26 December 2018

Corresponding author

Afnan Anis El-Wakeel

fontamah@yahoo.com

\begin{abstract}
Background: $\mathrm{HCV}$ is a contagious blood-borne virus that attacks the liver and can be deadly despite often having no visible health warnings. IL-18 is an important proinflammatory cytokine secreted from Kupffer cells. It is involved in the pathogenesis of $\mathrm{HCV}$ infection through modulating immune functions by regulating IFN- $\gamma$ production and promoting the development of Th1 immune
\end{abstract} responses.

Objective: The aim of this study is to measure serum level of Il-18 in chronic hepatitis C patients and compare between Il-18 levels and the degree of liver fibrosis.

Subjects \& Methods: This is a case control study. It was conducted in Clinical Pathology and Tropical Medicine Departments, Faculty of Medicine, Zagazig University Hospitals during the period from June 2017 to August 2017. Eighty four subjects were included in this study; they were classified into three groups as follows: Group 1: composed of 28 (17 males, 11 females) apparently healthy subjects their ages ranged from 27 to 61 years old. Group 2 :composed of 28 patients (15 males, 13 females) with HCV infection diagnosed as HCV RNA positive serum by RT-PCR with normal liver enzymes(ALT,AST), their ages ranged from 25 to 63 years old. Group 3 :composed of 28 patients (16 males, 12 females) with HCV infection diagnosed as HCV RNA positive serum by RTPCR with elevated liver enzymes (ALT,AST) their ages ranged from 29 to 64 years old. Formal consent was obtained from all individual and the study protocol was approved by the Zagazig medical research ethical committee. Seven $\mathrm{ml}$ of venous blood was withdrawn by sterile venipuncture and used for routine investigations including, complete liver function tests, HCV antibodies by ELISA and HCV-RNA by RT-PCR and IL-18 serum level by ELISA technique.

Results: Group III showed highly statistically significant increased ALT and AST when compared to both group I and group II. There were high statistical significant differences between the three studied groups as regard Albumin level, Prothrombin time, Concentration (\%) and INR. There was statistical significant increase in viral load by PCR in Group III compared to Group II. There were high statistical significant differences between Group III compared to both Group I and Group II in IL-18 level. there were statistical significance increase in IL-18 level with increase degree of liver fibrosis in both Group II \& Group III. There was positive significant correlation between IL-18 level and AST in Group III. There was positive high significant correlation between IL-18 level and viral load in Group III.

Conclusion: Serum IL-18 is significantly increase in chronic HCV patients and is correlated with liver fibrosis staging determined by fibroscan. So, IL-18 can be used as a non-invasive pro inflammatory marker for detection of the chronicity and severity of liver fibrosis in CHC.

Key words: HCV infection, Interleukin-18, IFN- $\gamma$

\section{INTRODUCTION}

epatitis $\mathrm{C}$ is a serious disease that is widely distributed in most parts of the world especially in Egypt ${ }^{[1]}$. It was formerly identified as a putative viral hepatitis occurring after transfusion of blood products or intravenous drug use. There was evidence that hepatitis $\mathrm{C}$ could lead to persistent infection in a high proportion of infected individuals, and could progress to chronic liver disease, cirrhosis and hepatocellular carcinoma $(\mathrm{HCC})^{[2]}$. 
Approximately $30 \%$ of patients with chronic HCV infection have persistently normal ALT levels. the majority of these patients have some degree of histological liver damage that may be significant in up to $20 \%$ of cases and might progress towards a more severe degree of liver fibrosis ${ }^{[3]}$. The assessment of disease progression not only provides useful information for diagnosis and therapeutic supervision judgment but also for monitoring disease ${ }^{[4]}$.

persistent exposure of kupffer cells to HCV will continuously activate kupffer cells leading to the ongoing release of cytokines like IL-18 attracting and activating more leukocytes. Likewise, continuous activation of infiltrating leukocytes leads to ongoing production of IL-18 that indirectly activate kupffer cells ${ }^{[5]}$.

Proinflammatory cytokines play a dual role in virus infection. In acute infection, these cytokines act as an antiviral and help to clear infection. On the other hand, these cytokines may stimulate inflammatory processes in chronic infection. Therefore, HCV-mediated activation of IL-18 from macrophages may activate quiescent hepatic stellate cells toward fibrosis and may be a potential target for therapeutic modalities ${ }^{[6]}$.

The aim of this study is to measure serum level of Il-18 in chronic hepatitis $\mathrm{C}$ patients and compare between Il-18 levels and the degree of liver fibrosis in hepatitis $\mathrm{C}$ viral infection.

\section{SUBJECTS AND METHODS}

This is a case control study. It was conducted in Clinical Pathology and Tropical Medicine Departments, Faculty of Medicine, Zagazig University Hospitals during the period from June 2017 to August 2017. Formal consent was obtained from all individual and the study protocol was approved by the Zagazig medical research ethical committee.

Eighty four subjects were included in this study; they were classified into three groups as follows:

Group 1: composed of 28 (17 males, 11 females) apparently healthy subjects their ages ranged from 27 to 61 years old .

Group 2 :composed of 28 patients (15 males,13 females) with $\mathrm{HCV}$ infection diagnosed as HCV RNA positive serum by RT-PCR with normal liver enzymes(ALT,AST), their ages ranged from 25 to 63 years old.

Group 3 :composed of 28 patients (16 males, 12 females) with HCV infection diagnosed as HCV RNA positive serum by RT-PCR with elevated liver enzymes (ALT,AST) their ages ranged from 29 to 64 years old.

\section{Inclusion criteria:}

- Patients with HCV infection who were conducted at department of Tropical Medicine in Zagazig University Hospitals.

- The diagnosis was supported by positive HCV-RNA detection by real time PCR.

Exclusion criteria:

- Patients with liver diseases other than HCV.

- Patients with other medical diseases .

- Administration of antiviral drugs.

Each group was subjected to the following:

\section{A. Control group:}

1. Routine laboratory investigations:

a. Complete blood count.

b. Liver, kidney function tests and random blood sugar.

2. Measurement of serum IL-18 levels.

B. Patient group:

1. Complete history taking

2. Clinical examination

3. Routine laboratory investigations: Complete blood picture, Liver, kidney function tests and random blood sugar.

4. Viral markers including: HCV antibody. HBsAg.

5. PCR

6. Specific laboratory investigations: Serum IL-18 level (has been determined by EnzymeLinked Immunosorbent Assay using SunRed ELISA kit (Shanghai Sunred Biological Technology Co.).

Imaging study: Abdominal ultrasonography, Fibroscan(Philips - IU22 MATRIX).

\section{STATISTICAL ANALYSIS}

The collected data were computerized and statistically analyzed using SPSS program version 18.0. Qualitative data were represented as frequencies and 
El-Amin et al

relative percentages. Results are expressed as means \pm SD. Comparison between groups was done by Chi-Square test. Mann Whiteny test was used when data is not normally distributed. ANOVA F-test
Zagazig University Medical Journals

was used to compare between more than two groups. Pearson's correlation coefficient was used to test correlation between variables. $\mathrm{P}<0.05$ was considered to be statistically significant.

\section{RESULTS}

Table 1 Comparison of demographic data of the three studied groups

\begin{tabular}{|c|c|c|c|c|c|c|c|c|}
\hline Variable & \multicolumn{2}{|c|}{$\begin{array}{c}\text { Group I } \\
(\mathbf{n}=28)\end{array}$} & \multicolumn{2}{|c|}{$\begin{array}{c}\text { Group II } \\
(n=28)\end{array}$} & \multicolumn{2}{|c|}{$\begin{array}{c}\text { Group III } \\
(\mathbf{n}=28)\end{array}$} & $\mathbf{F}$ & $\mathbf{p}$ \\
\hline $\begin{array}{l}\text { Age (years) } \\
\text { Mean } \pm \text { SD } \\
\text { Range }\end{array}$ & \multicolumn{2}{|c|}{$\begin{array}{c}45.39 \pm 9.31 \\
27-61\end{array}$} & \multicolumn{2}{|c|}{$\begin{array}{c}42.75 \pm 11.62 \\
25-63\end{array}$} & \multicolumn{2}{|c|}{$\begin{array}{c}43.64 \pm 10.23 \\
29-64\end{array}$} & 0.47 & $\begin{array}{l}0.36 \\
\text { NS }\end{array}$ \\
\hline & No & $\%$ & No & $\%$ & No & $\%$ & $\chi^{2}$ & $\mathbf{p}$ \\
\hline $\begin{array}{l}\text { Sex } \\
\text { Female } \\
\text { Male }\end{array}$ & $\begin{array}{l}11 \\
17\end{array}$ & $\begin{array}{l}39.3 \\
60.7\end{array}$ & $\begin{array}{l}13 \\
15\end{array}$ & $\begin{array}{l}46.4 \\
53.6\end{array}$ & $\begin{array}{l}12 \\
16\end{array}$ & $\begin{array}{l}42.9 \\
57.1\end{array}$ & 0.29 & $\begin{array}{l}0.86 \\
\text { NS }\end{array}$ \\
\hline
\end{tabular}

SD: Standard deviation, F: ANOVA test, $\chi^{2}$ : Chai square test. P: probability value. NS: nonsignificant $(\mathrm{P}>0.05)$

There were no statistical significant differences between the three studied groups in age or sex distribution ( $\mathrm{p}$ value $>0.05$ ).

Table 2 Comparison between different studied groups regarding ALT and AST

\begin{tabular}{|c|c|c|c|c|c|c|}
\hline Variable & $\begin{array}{c}\text { Group I } \\
(\mathbf{n}=\mathbf{2 8})\end{array}$ & $\begin{array}{c}\text { Group II } \\
(n=28)\end{array}$ & $\begin{array}{c}\text { Group III } \\
(\mathbf{n}=\mathbf{2 8})\end{array}$ & Test & $\mathbf{P}$ & LSD \\
\hline $\begin{array}{l}\text { ALT(U/L) } \\
\text { Mean } \pm \text { SD } \\
\text { Range }\end{array}$ & $\begin{array}{c}20.64 \pm 6.73 \\
11-32\end{array}$ & $\begin{array}{c}28.04 \pm 7.32 \\
14-40\end{array}$ & $\begin{array}{c}119.5 \pm 74.04 \\
47-348\end{array}$ & $\begin{array}{c}K \\
61.01\end{array}$ & $<0.001 * *$ & $\begin{array}{l}0.52 \mathrm{NS}^{1} \\
<0.001 * * 2 \\
<0.001 * *{ }^{2}\end{array}$ \\
\hline $\begin{array}{l}\text { AST (U/L) } \\
\text { Mean } \pm \text { SD } \\
\text { Range }\end{array}$ & $\begin{array}{c}30.5 \pm 5.63 \\
19-40\end{array}$ & $\begin{array}{c}31.29 \pm 5.90 \\
20-40\end{array}$ & $\begin{array}{c}101.18 \pm 45.61 \\
46-204\end{array}$ & $\begin{array}{c}\mathrm{K} \\
\mathbf{5 5 . 4 7}\end{array}$ & $<0.001 * *$ & $\begin{array}{c}0.91 \mathrm{NS}^{1} \\
<\mathbf{0 . 0 0 1} * * *^{2} \\
<\mathbf{0 . 0 0 1} * * *^{3}\end{array}$ \\
\hline
\end{tabular}

F: ANOVA test K:Kruskal Wallis test LSD: Least significance difference

NS: Non significant $\quad(\mathrm{p}>0.05) \quad * *$ :Highly significant $(\mathrm{p}<0.01) \quad *$ :Significant $(\mathrm{p}<0.05)$

P1: Group I versus Group II, $\quad$ P2: Group I versus Group III $\quad$ P3: Group II versus Group III

This table shows that there were high statistical significance differences between the three studied groups as regard serum ALT and AST. The difference was between Group III compared to both group I and II but no difference was found between Group I and Group II. 
El-Amin et al

Table 3 Comparison between different studied groups regarding mean values of Total and Direct bilirubin, Albumin level, Prothrombin time, Concentration (\%) and INR

\begin{tabular}{|c|c|c|c|c|c|c|}
\hline Variable & $\begin{array}{c}\text { Group I } \\
(\mathbf{n}=28)\end{array}$ & $\begin{array}{c}\text { Group II } \\
(\mathbf{n}=28)\end{array}$ & $\begin{array}{l}\text { Group III } \\
(\mathbf{n}=28)\end{array}$ & Test & $\mathbf{P}$ & LSD \\
\hline $\begin{array}{l}\text { T.Bilirubin }(\mathbf{m g} / \mathbf{d l}) \\
\text { Mean } \pm \text { SD } \\
\text { Range }\end{array}$ & $\begin{array}{c}0.69 \pm 0.22 \\
0.40-1\end{array}$ & $\begin{array}{c}0.80 \pm 0.28 \\
0.5-1.2\end{array}$ & $\begin{array}{c}0.83 \pm 0.20 \\
0.3-1.5\end{array}$ & $\begin{array}{c}\mathrm{F} \\
2.74\end{array}$ & $\begin{array}{l}0.07 \\
\mathrm{NS}\end{array}$ & ----- \\
\hline $\begin{array}{l}\text { D.Bilirubin }(\mathbf{m g} / \mathbf{d l}) \\
\text { Mean } \pm \text { SD } \\
\text { Range }\end{array}$ & $\begin{array}{c}0.14 \pm 0.07 \\
0.1-0.3\end{array}$ & $\begin{array}{c}0.16 \pm 0.07 \\
0.1-0.3\end{array}$ & $\begin{array}{c}0.18 \pm 0.10 \\
0.1-0.4\end{array}$ & $\begin{array}{c}\mathrm{K} \\
2.13\end{array}$ & $\begin{array}{l}0.16 \\
\mathrm{NS}\end{array}$ & ---- \\
\hline $\begin{array}{l}\text { Albumin }(\mathbf{m g} / \mathbf{d l}) \\
\text { Mean } \pm \text { SD } \\
\text { Range }\end{array}$ & $\begin{array}{c}4.75 \pm 0.35 \\
3.4-5.1\end{array}$ & $\begin{array}{c}4.52 \pm 0.28 \\
4.1-5.1 \\
\end{array}$ & $\begin{array}{c}4.26 \pm 0.55 \\
2.7-4.5 \\
\end{array}$ & $\begin{array}{c}F \\
10.03\end{array}$ & $<0.001 * *$ & $\begin{array}{c}\mathbf{0 . 0 4} *^{1} \\
<0.001 * *^{2} \\
\mathbf{0 . 0 3}^{*}{ }^{3} \\
\end{array}$ \\
\hline $\begin{array}{l}\text { Prothrombin(sec.) } \\
\text { Mean } \pm \text { SD } \\
\text { Range } \\
\end{array}$ & $\begin{array}{c}12.21 \pm 0.28 \\
12.3-13.3 \\
\end{array}$ & $\begin{array}{c}12.43 \pm 0.29 \\
12.3-13.3 \\
\end{array}$ & $\begin{array}{c}12.75 \pm 0.66 \\
12.3-14.8 \\
\end{array}$ & $\begin{array}{c}F \\
10.36\end{array}$ & $<0.001 * *$ & $\begin{array}{c}\mathbf{0 . 0 4}^{* 1} \\
<0.001 * *^{2} \\
0.009 * 3 \\
\end{array}$ \\
\hline $\begin{array}{l}\text { Concentration (\%) } \\
\text { Mean } \pm \text { SD } \\
\text { Range } \\
\end{array}$ & $\begin{array}{c}89.29 \pm 4.11 \\
80-95\end{array}$ & $\begin{array}{c}92.91 \pm 4.25 \\
85-95 \\
\end{array}$ & $\begin{array}{c}96.93 \pm 9.22 \\
87.5-100 \\
\end{array}$ & $\begin{array}{c}F \\
10.23\end{array}$ & $<0.001 * *$ & $\begin{array}{c}\mathbf{0 . 0 3}^{* 1} \\
<\mathbf{0 . 0 0 1}^{*} *^{2} \\
\mathbf{0 . 0 0 3}_{* *}^{3} \\
\end{array}$ \\
\hline $\begin{array}{l}\text { INR } \\
\text { Mean } \pm \text { SD } \\
\text { Range } \\
\end{array}$ & $\begin{array}{c}0.98 \pm 0.07 \\
1-1.05 \\
\end{array}$ & $\begin{array}{c}1.02 \pm 0.05 \\
1-1.15 \\
\end{array}$ & $\begin{array}{c}1.06 \pm 0.08 \\
1-1.24 \\
\end{array}$ & $\begin{array}{c}F \\
9.74\end{array}$ & $<0.001 * *$ & $\begin{array}{c}\mathbf{0 . 0 2}^{* 1} \\
<\mathbf{0 . 0 0 1}^{*} *^{2} \\
\mathbf{0 . 0 2}^{2} *^{3}\end{array}$ \\
\hline
\end{tabular}

F: ANOVA test K:Kruskal Wallis test LSD: Least significance difference

NS: Non significant $\quad(\mathrm{p}>0.05) \quad * *$ :Highly significant $(\mathrm{p}<0.01) \quad *$ :Significant $(\mathrm{p}<0.05)$

P1: Group I versus Group II, P2: Group I versus Group III P3: Group II versus Group III

This table shows that there were high differences between the three studied groups statistical significant differences between the as regard Total and Direct bilirubin. In three studied groups as regard Albumin level, Albumin level, Prothrombin time, Prothrombin time, Concentration (\%) and Concenteartion and INR the difference was INR but there were no statistical significant between all groups.

Table 4 Comparison of PCR results among the two patient groups

\begin{tabular}{|l|c|c|c|c|}
\hline \multicolumn{1}{|c|}{ Variable } & $\begin{array}{c}\text { Group II } \\
(\mathbf{n = 2 8})\end{array}$ & $\begin{array}{c}\text { Group III } \\
(\mathbf{n = 2 8})\end{array}$ & MW & P \\
\hline PCR: & $1113300 \pm 815062$ & $1408600 \pm 610970$ & & \\
Mean \pm SD & $11500-2360000$ & $174000-2930000$ & $\mathbf{2 . 3 8}$ & $\mathbf{0 . 0 4 *}$ \\
Range
\end{tabular}

MW: Mann Whiteny test $\quad$ *:Significant $(\mathrm{p}<0.05)$

This table shows that there were statistical significant increase in viral load by PCR in Group III compared to Group II.

Table 5 Comparison between different studied groups regarding mean values of IL-18 (ng/l)

\begin{tabular}{|c|c|c|c|c|c|c|}
\hline Variable & $\begin{array}{c}\text { Group I } \\
(\mathbf{n}=\mathbf{2 8})\end{array}$ & $\begin{array}{c}\text { Group II } \\
(\mathbf{n}=\mathbf{2 8})\end{array}$ & $\begin{array}{c}\text { Group III } \\
(\mathbf{n}=\mathbf{2 8})\end{array}$ & $\mathbf{K}$ & $\mathbf{P}$ & LSD \\
\hline $\begin{array}{l}\text { IL-18 (ng/l) } \\
\text { Mean } \pm \text { SD } \\
\text { Range }\end{array}$ & $\begin{array}{c}19.98 \pm 12.45 \\
9-25\end{array}$ & $\begin{array}{c}23.46 \pm 12.13 \\
6-45\end{array}$ & $\begin{array}{c}37.21 \pm 16.2 \\
14-64\end{array}$ & 13.56 & $0.003 * *$ & $\begin{array}{l}0.06 \mathrm{NS}^{1} \\
<\mathbf{0 . 0 0 1} * * *^{2} \\
<\mathbf{0 . 0 0 1} * *^{3}\end{array}$ \\
\hline
\end{tabular}

$\mathrm{K}:$ Kruskal Wallis test

**: Highly Significant $(\mathrm{p}<0.01)$

P1: Group I versus Group II,
LSD: Least significance difference

NS: Non significant $(\mathrm{P}>0.05)$

P2: Group I versus Group III P3: Group II versus Group III 
This table shows that there were high statistical significant differences between the three studied groups in IL-18. Using LSD to find difference between groups showed that the difference was between Group III compared to both Group I and Group II.

Table 6 Description of IL-18 results and degree of liver fibrosis in patients groups

\begin{tabular}{|c|c|c|c|c|c|}
\hline & & \multicolumn{2}{|c|}{ IL-18 } & K & P \\
\cline { 3 - 6 } Fibrosis & $\mathbf{N}$ & Mean \pm SD & Range & & \\
\hline F1 & 19 & $16.53 \pm 5.19$ & $6-20$ & & \\
F2 & 12 & $22.3 \pm 6.10$ & $16-25$ & $\mathbf{1 9 . 9}$ & \\
F3 & 14 & $32.15 \pm 11.5$ & $20-38$ & & $<\mathbf{0 . 0 0 1 * *}$ \\
F4 & 11 & $50.29 \pm 21.91$ & $29-64$ & & \\
\hline
\end{tabular}

K:Kruskal Wallis test

**: Highly Significant $(\mathrm{p}<0.01)$

This table shows that there was positive high relation between degree of liver fibrosis and level of IL-18 in HCV patients.

Table 7 Correlation between IL-18 and age, PCR results, Liver Fibrosis \& laboratory parameters of the three studied groups

\begin{tabular}{|c|c|c|c|c|}
\hline & \multicolumn{3}{|c|}{ IL-18 } \\
\hline \multicolumn{2}{|c|}{ Variable } & Group & Group II & Group III \\
\hline \multirow[t]{2}{*}{ Age } & $\mathrm{r}$ & 0.11 & 0.03 & 0.36 \\
\hline & $\mathrm{p}$ & 0.59 & 0.87 & 0.06 \\
\hline \multirow[t]{2}{*}{ PCR results } & $\mathrm{r}$ & $\begin{array}{ll}---- \\
\end{array}$ & 0.12 & 0.55 \\
\hline & $\mathrm{p}$ & & 0.55 & $<0.001 * *$ \\
\hline \multirow[t]{2}{*}{ Liver Fibrosis } & $\mathrm{r}$ & ---- & $\mathbf{0 . 8 0}$ & 0.78 \\
\hline & $\mathrm{p}$ & & $<0.001 * *$ & $<0.001 * *$ \\
\hline \multirow[t]{2}{*}{ ALT } & $\mathrm{r}$ & 0.24 & 0.13 & 0.14 \\
\hline & $\mathrm{p}$ & 0.22 & 0.12 & 0.49 \\
\hline \multirow[t]{2}{*}{ AST } & $\mathrm{r}$ & 0.17 & 0.06 & 0.32 \\
\hline & $\mathrm{p}$ & 0.40 & 0.76 & 0.03* \\
\hline \multirow[t]{2}{*}{ T.Bilirubin } & $\mathrm{r}$ & -0.11 & -0.05 & 0.01 \\
\hline & $\mathrm{p}$ & 0.59 & 0.81 & 0.95 \\
\hline \multirow[t]{2}{*}{ D.Bilirubin } & $\mathrm{r}$ & -0.10 & -0.02 & 0.08 \\
\hline & $\mathrm{p}$ & 0.61 & 0.94 & 0.70 \\
\hline \multirow[t]{2}{*}{ Albumin } & $\mathrm{r}$ & -0.29 & -0.03 & -0.09 \\
\hline & $\mathrm{p}$ & 0.06 & 0.89 & 0.64 \\
\hline \multirow[t]{2}{*}{ Prothrombin Time } & $\mathrm{r}$ & 0.06 & 0.15 & 0.22 \\
\hline & $\mathrm{p}$ & 0.76 & 0.45 & 0.26 \\
\hline \multirow[t]{2}{*}{ Concentration } & $\mathrm{r}$ & -0.07 & -0.15 & -0.22 \\
\hline & $\mathrm{p}$ & 0.78 & 0.45 & 0.26 \\
\hline \multirow[t]{2}{*}{ INR } & $\mathrm{r}$ & 0.21 & 0.15 & 0.22 \\
\hline & $\mathrm{p}$ & 0.25 & 0.45 & 0.26 \\
\hline
\end{tabular}

$\mathrm{r}=$ Pearson correlation coefficient $\quad * *$ : Highly Significant $(\mathrm{p}<0.01) *$ :Significant $(\mathrm{p}<0.05)$

This table shows that there were high statistical significant positive correlation between IL-18 level and liver fibrosis in both Group II \& Group III. Also there were positive significant correlation between IL-18 level and AST in Group III. Also, there were positive high significant correlation between IL-18 level and viral load in Group III.

DISCUSSION 
$\mathrm{HCV}$ infection is a major health problem in Egypt as the nation bears the highest prevalence rate worldwide ${ }^{[7]}$. Chronic infection with $\mathrm{HCV}$ is the leading cause of end stage liver disease, HCC and liver-related death in the country ${ }^{[8]}$.

liver function tests are insensitive for predicting disease progression. Serum ALT may be elevated in patients without significant histological abnormality. Similarly, normal values do not exclude progressive liver disease or cirrhosis ${ }^{[9]}$. Different invasive and non-invasive methods are applied to diagnose the disease from initial to end stage ${ }^{[10]}$.

Percutaneous liver biopsy has been considered the golden standard for the histological assessment of liver fibrosis ${ }^{[11]}$. However, liver biopsy has several limitations. The procedure is invasive and painful, with the risk of rare but potential life-threatening complications $^{[12]}$

FibroScan is a non-invasive test that assesses stiffness in the liver ${ }^{[13]}$. Its results had good correlation with the histology of liver fibrosis in patients with hepatitis $C^{[14]}$. However, measurements can be difficult to obtain in obese patients or in those who have narrow intercostal spaces, and is impossible to achieve in patients with ascites ${ }^{[15]}$.

Once hepatocytes are productively infected with HCV, cellular defenses become activated. Hepatocytes trigger kupffer cells to produce cytokines such as IL-18 to recruit IFN- $\gamma$ producing NK cells to the liver ${ }^{[16]}$. IL18 is a proinflammatory cytokine with immunomodulatory functions by enhancing $\mathrm{T}$ cell responses, regulating IFN- $\gamma$ production and promoting the development of Th1 immune responses ${ }^{[17]}$. Hepatic inflammatory activity in chronic hepatitis $\mathrm{C}$ was shown to be closely associated with an increased amount of IL- $18^{[18]}$.

The present study was carried on 84 subjects classified into 3 groups: Group I included 28 healthy subjects, 17 were males $(60.7 \%)$ and 11 were females $(39.3 \%)$, their ages ranged from 27 to 61 years with mean ages $45.39 \pm 9.31$, Group II included 28 patients with chronic hepatitis $\mathrm{C}$ with normal liver enzymes, 15 were males(53.6\%) and 13 were females $(46.4 \%)$, their ages ranged from
25 to 63 years with mean ages $42.75 \pm 11.62$ and Group III included 28 patients with chronic hepatitis $\mathrm{C}$ with elevated liver enzymes, 16 were males(57.1\%) and 12 were females $(42.9 \%)$, their ages ranged from 29 to 64 years with mean ages $43.64 \pm 10.23$ with no statistical significant differences between the three studied groups in age or sex distribution ( $\mathrm{p}$ value $>0.05$ )

The present study showed high statistical significant differences between the three studied groups as regard serum ALT $(\mathrm{K}=61.01)$ and AST $(\mathrm{K}=55.47)$. The difference was between Group III compared to both group I and II (p value $<0.01$ ) but no difference was found between Group I and Group II ( $p$ value >0.05). Increases of serum AST activity generally parallel those of ALT and are therefore considered to be a sensitive marker for hepatocellular injury ${ }^{[19]}$. However, Wedemeyer et al., found that the cause of normal liver enzymes in patients with chronic hepatitis $\mathrm{C}$ may be related to host factors particularly immunologic, where possible equilibrium between $\mathrm{HCV}$ replication and host immune response results in weak or no cell mediated response directed to $\mathrm{HCV}$ infected cells ${ }^{[20]}$.

In the present study there were high statistical significant differences between the three studied groups as regard Albumin level $(\mathrm{F}=10.03)$, Prothrombin time $(\mathrm{F}=10.36)$, Concentration $(\%) \quad(\mathrm{F}=10.23)$ and INR $(\mathrm{F}=9.74)$,but there were no statistical significant differences between the three studied groups as regard Total and Direct bilirubin ( $p$ value >0.05). The difference in Albumin level, Prothrombin time, Concenteartion and INR was between all groups ( $\mathrm{p}$ value $<0.05$ ). Sherlock \& Dooley, stated that the liver function tests usually indicate the type and severity of liver injury ${ }^{[21]}$. Both decreased Albumin and the Albumin/Globulin (A/G) levels were indicators of serious liver damage ${ }^{[22]}$.

In the present study there was statistical significant increase in viral load by PCR in Group III compared to Group II (MW=2.38 , $\mathrm{p}$ value $<0.05)$. Determination of HCV RNA levels has become an essential part of patient care, from early diagnosis of infection to treatment monitoring ${ }^{[23]}$. 
The present study showed high statistical significant level of IL-18 in group III when compared with both group I and II ( $\mathrm{p}$ value $<0.001$ ) while there was no statistically significant difference between group I and group II regarding IL-18 level ( $\mathrm{p}$ value $=0.06$ ). This explained that group II with normal enzymes not associated with viral activity that accompanied with proinflammatory expression of IL-18. Zhang et al., showed that IL-18 level in the serum of the chronic hepatitis $\mathrm{C}$ group was higher than that of the healthy control group ${ }^{[24]}$. The same findings were observed by Niu et al., who demonstrated a positive association between CHC and plasma IL-18 levels ${ }^{[25]}$.

In the present study there was positive high relation between degree of liver fibrosis and serum level of IL-18 in HCV patients $(\mathrm{K}=19.9$, $\mathrm{P}$ value $<0.001)$. It is possible that up-regulation of IL-18 production has a role in the development of chronicity and accelerates the evolution of chronic hepatitis towards cirrhosis ${ }^{[26]}$. In accordance with these results, Said et al., observed positive correlation between IL-18 serum level both METAVIR necroinflammatory grade and fibrosis stage ${ }^{[27]}$.

The present study showed no correlation between IL-18 and age, ALT, T.Bilirubin, D.Bilirubin, Albumin, Prothrombin Time, Concentration, INR. However, there was nonsignificant positive correlation between serum IL-18 and AST in group II ( $r=0.06, \mathrm{P}$ value $=0.76$ ) while there was significant positive correlation between serum IL-18 and AST in group III ( $\mathrm{r}=0.32$, $\mathrm{P}$ value $=0.03$ ). This is in agreement with some authors who suggested that serum aminotransferases, especially the AST level, were associated with liver damage explaining more release of AST from liver cell injury in group $\amalg^{[28]}$.

In the present study there was positive high significant correlation between IL-18 level and viral load in Group III $(\mathrm{r}=0.55, \mathrm{p}$ value $<0.01)$. Patients treated with PEG-IFN and ribavirin showed high relation between serum IL-18 level and HCV-RNA titers ${ }^{[29]}$.

\section{CONCLUSION}

This study revealed that Serum IL-18 is significantly increase in chronic HCV patients and is correlated with liver fibrosis staging determined by fibroscan. So, IL-18 can be used as non-invasive pro inflammatory marker for detection of the chronicity and severity of liver fibrosis in chronic hepatitis c patients. Further studies are needed on large number of subjects to investigate IL-18 response to infection with various genotypes of HCV (specifically genotype 4). Follow up of patients is recommended to detect the association between serum IL-18 levels and response to different treatment modalities.

\section{REFERENCES}

1. Wasley, A. and Alter, M.J. (2000). Epidemiology of hepatitis C: geographic differences and temporal trends. In Seminars in liver disease (Vol. 20, No. 01, pp. 0001-0016). Copyright $\odot 2000$ by Thieme Medical Publishers, Inc., 333 Seventh Avenue, New York, NY 10001, USA. Tel.:+ 1 (212) 5844663.

2. Mohd Hanafiah, K., Groeger, J., Flaxman, A.D. and Wiersma, S.T.. Global epidemiology of hepatitis $\mathrm{C}$ virus infection: New estimates of age-specific antibody to $\mathrm{HCV}$ seroprevalence. Hepatology, 2013; 57(4) : 1333-1342.

3. Puoti, C., Guarisco, R., Spilabotti, L., Bellis, L., Mitidieri Costanza, O., Dell'Unto, O., et al. Should we treat HCV carriers with normal ALT levels? The ' $5 \mathrm{Ws}$ ' dilemma. Journal of viral hepatitis, 2012; 19(4) : 229-235.

4. Ahmad, S., Ijaz, B., Gull, S., Asad, S., Khaliq, S., Jahan, S.,et al.. A brief review on molecular, genetic and imaging techniques for $\mathrm{HCV}$ fibrosis evaluation. Virology Journal; 2011; 8:53.

5. Boltjes, A., Movita, D., Boonstra, A. and Woltman, A.M. (2014). The role of Kupffer cells in hepatitis $\mathrm{B}$ and hepatitis $\mathrm{C}$ virus infections. Journal of hepatology, 2014; 61(3) : 660-671.

6. Shrivastava, S., Mukherjee, A., Ray, R. and Ray, R.B.. Hepatitis C virus induces interleukin$1 \beta$ (IL-1 $\beta) / \mathrm{IL}-18$ in circulatory and resident liver macrophages. Journal of virology, 2013; 87(22) : 12284-12290.

7. El-Akel, W., El-Sayed, M.H., El Kassas, M., El-Serafy, M., Khairy, M., Elsaeed, K. et al. National treatment programme of hepatitis $\mathrm{C}$ in Egypt: Hepatitis $\mathrm{C}$ virus model of care. Journal of viral hepatitis, 2017; 24(4): 262-267.

8. Westbrook, R.H. and Dusheiko, G.. Natural history of hepatitis C. Journal of hepatology, 2014; 61(1): S58-S68.

9. Buchanan R. and Nash K.L.. Hepatitis C. Medicine, 2015; 43(10) : pp.607-612. Available at (http: // www.medicinejournal.co.uk/ article/ S1357-3039(15)001917/fulltext). 


\section{El-Amin et al}

10. Ahmad, S., Ijaz, B., Gull, S., Asad, S., Khaliq, S., Jahan, S.,et al.. A brief review on molecular, genetic and imaging techniques for HCV fibrosis evaluation. Virology Journal; 2011; 8:53.

11.Dienstag, J.L.. The role of liver biopsy in chronic hepatitis C. Hepatology, 2002; 36(5B).

12.Bravo, A.A., Sheth, S.G. and Chopra, S.. Liver biopsy. New England Journal of Medicine, 2001; 344(7), 495-500.

13.Harrison, S.A.. Utilization of FibroScan Testing in Hepatitis $\mathrm{C}$ Virus Management. Gastroenterology \& hepatology, 2015; 11(3) : 187.

14.Nakamura, Y., Aikata, H., Fukuhara, T., Honda, F., Morio, K., Morio, R. et al.. Liver fibrosis assessment by FibroScan compared with pathological findings of liver resection specimen in hepatitis $\mathrm{C}$ infection. Hepatology Research, 2017; 47(8) : 767-772.

15. Foucher, J., Castéra, L., Bernard, P.H., Adhoute, X., Laharie, D., Bertet, J. et al.. Prevalence and factors associated with failure of liver stiffness measurement using FibroScan in a prospective study of 2114 examinations. European journal of gastroenterology \& hepatology, 2006; 18(4) : 411-412.

16. Kaplan, D.E.. Immunopathogenesis of hepatitis $C$ virus Infection. Gastroenterology Clinics, 2015; 44(4) : 735-760.

17.Dembic, Z.. Cytokines of the immune system: interleukins. The cytokines of the immune system the role of cytokines in disease related to immune response. San Diego: Mica Haley, 2015; 143-239.

18. YingLi, H., Shumei, L., Qian, Y., Tianyan, C., Yingren, Z. and Wei, C.. Proapoptotic IL-18 in patients with chronic hepatitis $\mathrm{C}$ treated with pegylated interferon-alpha. Clinical and experimental medicine, 2009; 9(2) : 173-178.

19.Lawrence, Y. A. and Steiner, J. M.. Laboratory Evaluation of the Liver. Veterinary Clinics: Small Animal Practice, 2017; 47(3) : 539-553.

20.Wedemeyer, H., Jäckel, E., Wiegand, J., Cornberg, M. and Manns, M.P.. Whom? When? How? Another piece of evidence for early treatment of acute hepatitis C. Hepatology, 2004; 39(5) : 1201-1203.

21. Sherlock, S. and Dooley, J.. Assessment of liver function. Diseases of the Liver and Biliary

\section{Zagazig University Medical Journals}

System. 11th ed. Oxford: Blackwell Publishing; 2002: 19-35.

22. Tian, L., Wang, Y., Xu, D., Gui, J., Jia, X., Tong, H., Wen, X., Dong, Z., and Tian, Y. (2011). Serological AFP/Golgi protein 73 could be a new diagnostic parameter of hepatic diseases. International journal of cancer, 2011; 129(8) : 1923-1931.

23.Laperche, S., Le Marrec, N., Girault, A., Bouchardeau, F., Servant-Delmas, A., ManiezMontreuil, M.. Simultaneous detection of hepatitis $\mathrm{C}$ virus (HCV) core antigen and anti$\mathrm{HCV}$ antibodies improves the early detection of $\mathrm{HCV}$ infection. Journal of clinical microbiology, 2005; 43(8) : 3877-3883.

24. Zhang, L., Hao, C.Q., Miao, L. and Dou, X.G.. Role of Th1/Th2 cytokines in serum on the pathogenesis of chronic hepatitis $\mathrm{C}$ and the outcome of interferon therapy. Genet Mol Res, 2014; 13(4) : 9747-55.

25.Niu, Z., Zhang, P. and Tong, Y.. Association of plasma interleukin-18 levels and polymorphisms in interleukin-18 gene with outcomes of hepatitis $C$ virus infections: a meta-analysis. Journal of Immunoassay and Immunochemistry, 2015; $36(3): 221-232$.

26. Sharma, A., Chakraborti, A., Das, A., Dhiman, R.K. and Chawla, Y.. Elevation of interleukin-18 in chronic hepatitis $\mathrm{C}$ : implications for hepatitis C virus pathogenesis. Immunology, 2009; 128 (1pt2).

27.Said, E.M., Soliman, M.S., Rashed, M.S., El Azm, A.A., Zakaria, R. and El Salam, F.A.. P784 interleukin-18 and its gene polymorphisms influence the progression of chronic hepatitis $\mathrm{c}$. Journal of Hepatology, 2014; 60(1) : S331-S332.

28.Zechini, B., Pasquazzi, C. and Aceti, A.. Correlation of serum aminotransferases with HCV RNA levels and histological findings in patients with chronic hepatitis $\mathrm{C}$ : the role of serum aspartate transaminase in the evaluation of disease progression. European journal of gastroenterology \& hepatology, 2004; 16(9) : 891-896.

29.Murata, K., Yamamoto, N., Kawakita, T., Saito, Y., Yamanaka, Y., Sugimoto, K.. Up-regulation of IL-18 by interferon alpha-2b/ribavirin combination therapy induces an anti-viral effect in patients with chronic hepatitis C. Hepatogastroenterology,2005; 52(62): 547-551.

How to cite this article: El-Amin MM, El-Khashab MN, Ibrahim HA, El-Wakeel AA. Estimation of serum interleukin-18 in hepatitis C patients in Zagazig University Hospitals. ZUMJ 2019; 25 (1): 71-78. 